Vol. 37(2), pp. 155-166, Dec. 2018

ISSN 1821-536X (print)

ISSN 2619-8789 (electronic)

Full Length Research Paper
Tanzania Journal of Engineering and Technology

Copyright (c) 2018 College of Engineering and

Technology, University of Dar es Salaam

\title{
Effects of Methyl-blue Addition in Sewage Substrate on the Performance of Microbial Fuel Cell
}

\author{
Joseph Kihedu* and John Geophrey
}

Department of Mechanical and Industrial Engineering, University of Dar es Salaam, P.O. Box 35131, Dar es Salaam, Tanzania.

*Corresponding author: kihedu@udsm.ac.tz

\begin{abstract}
Experimental study was undertaken to evaluate performance of microbial fuel cell. Without addition of methyl blue, the cell generated $1.265 \mathrm{~V}, 0.403 \mathrm{~mA}$ and $56.12 \mathrm{~mW} / \mathrm{m}^{2}$ after three hours of operation. With $300 \mu \mathrm{M}$ methyl blue in sewage anolyte, $6.7 \%$ increase in voltage, $20.5 \%$ increase in current and $28.6 \%$ increase in power density was observed. By using ashwater catholyte, addition of methyl blue in anolyte led to increase of $9.0 \%$ in voltage, $38.5 \%$ in current and $50.9 \%$ for power density. Between three and twenty four hours of continuous operation of the cell with phosphate buffer catholyte, the average voltage was $1.305 \mathrm{~V}$ and the average current was $0.321 \mathrm{~mA}$ before addition of methyl blue. Methyl blue addition led to $5.1 \%$ increase in voltage and $55.2 \%$ increase in current. For the case of ash-water catholyte with methyl blue in anolyte, led to $6.2 \%$ increase in voltage and $59.1 \%$ increase in current.
\end{abstract}

Keywords: Methyl-blue, Microbial fuel cell, Phosphate buffer, Sewage anolyte.

\section{INTRODUCTION}

Microbial Fuel Cell (MFC) technologies represent a new approach for generating electricity from biomass by using bacteria. MFC is a bio-electrochemical device that through microbial-catalyzed redox reactions convert the energy stored within bio-convertible substrates to electricity (Permana et al., 2015). It works similar to many other types of fuel cells. As opposed to the other types of fuel cells, MFC uses bacteria to generate electricity from the breakdown of organic substrates. The fundamental physical components of a typical dual-chamber MFC includes the electrolytes, an anode and a cathode partitioned by a Proton Exchange Membrane (PEM) also known as Cation Exchange Membrane (CEM). In the anode chamber, the bacteria oxidizes these substances to generate protons and electrons (Rabaey et al., 2005). The electrons are attracted to the electron accepting molecules in the cathode, and are transferred through the external circuit and are further used to produce electrical energy. Protons are exchanged from the anode to the cathode through the CEM, thus balancing the charge of the overall system. Bacteria gain energy for metabolism and reproduction by transferring electrons and protons from a reduced substrate at a lower potential to an electron acceptor at a higher potential $(\mathrm{Li}$ et al., 2014).

Anode should be available with a higher positive potential than other possible substrates in the waste stream, such as 
sulphate or iron, so that the energetic gain will be much higher for bacteria that can deliver to the anode (Logan and Regan, 2006). However, if the anode potential is too low, electricity production will cease and fermentation processes will start. Several methods have been shown to increase anode performance beyond the standard graphite electrode: from bioengineering a reconstituted glucose oxidase monolayer (Katz et al., 2003) to bound electron mediators including $\mathrm{Mn}^{4+}$ graphite and neutral red covalently linked woven graphite anodes (Park and Zeikus, 2000). Cathode plays important factor in the performance of a MFC due to the poor kinetics of oxygen reduction reaction in a neutral pH medium (Cheng et al., 2004). Other physical and chemical environmental effects also influence the thermodynamics and the kinetics of the electro catalytic oxygen reduction (Zhao et al., 2006). There are two general options for a cathode, either a chamber filled with some form of dissolved electron acceptor or a chamber with less cathode that is exposed directly to oxygen in the air. Proton or cation exchange membrane (PEM/CEM) can be used to separate the cathode and anode liquids into different chambers, or just to act as a barrier that keeps materials other than protons from reaching the cathode (Logan et al., 2006).

The first observation of electrical current generated by bacteria is generally credited to Potter's elementary work (Ieropoulos $e t$ al., 2005). This didn't generate much interest until when it was discovered that current density and the power output could be greatly enhanced by the addition of electron mediators. Electron mediators accelerate the transfer from inside the cell to exogenous electrodes (Davis and Higson, 2007). Studies of MFCs indicate that the efficiency of operation of MFCs depend much on rate of electron transfer from microorganism (You et al., 2006). The major drawback is that the rate of electron transfer from bacteria is too small for high electricity generation. The electron transfer from microbial cells to the electrode can be facilitated by mediators such as thionine, methyl viologen, methyl blue, humic acid, ferric cyanide, and neutral red (Permana et al., 2015). Some of mediators are too expensive and some are highly poisonous like thionine. Dissolved artificial electron mediators assist the electron transfer from bacterial cells to the electrode and further routed through an external circuit to the cathode to deliver electrical energy. Mediators in an oxidized state can easily be reduced by capturing the electrons from within the membrane. The mediators then move across the membrane and release the electrons to the anode and become oxidized again in the bulk solution in the anodic chamber (Parkash et al., 2015). This cyclic process accelerates the electron transfer rate and thus increases the power output.

The use of sewage and ash for electricity generation paves new potential for complementing decentralized resources for off-grid solutions. Along with decentralized availability of sewage and ash from domestic cooking stoves, MFC provides relatively cheaper electricity generation technology. Other common alternatives resources for off-grid electricity generation include solar PV, wind turbines and microhydro (Kihedu and Mhilu, 2012). However, rural electrification through use of these resources, shows slow penetration among the target rural population in developing countries. Among other factors hindering the expected success in rural electrification by using these resources, include higher investment costs for relevant technologies (Kimambo and Kihedu, 2008). Therefore MFC technology need to be developed and explored. This study analyzed effects of methyl blue mediator as electrons prompter in microbial fuel cell for power generation. Charcoal anode is used instead of graphite, copper, platinum or $\mathrm{Ti}-\mathrm{TiO}_{2}$ 
used by other researchers (Rabaey et al., 2004; Ghangrekar and Shinde, 2006; Davis and Higson, 2007; Permana et al., 2015; Taskan et al., 2014).

\section{MATERIALS AND METHODS}

\section{Laboratory scale microbial fuel cell}

Microbial fuel cell (MFC) used featured two chambers built in $\mathrm{H}$ shape, consisting of two heavy duty rectangular polyethylene containers, each with 2,200 $\mathrm{cm}^{3}$ volume and with sealable lids (Figure 1A). Containers were connected by using $10 \mathrm{~cm}$ PVC pipe containing a separator that served as Cation Exchange Membrane (CEM). CEM was made from solution of $\mathrm{NaCl} 0.04 \mathrm{~g} / \mathrm{cm}^{3}$ distilled water heated to $85{ }^{\circ} \mathrm{C}$, then agar powder was added and the hot mixture was stirred. The mixture was poured to the $10 \mathrm{~cm}$ PVC pipe and allowed to solidify to form salt bridge between the polyethylene containers. Charcoal anode of $3.5 \mathrm{~cm}$ internal diameter and $6.5 \mathrm{~cm}$ long was used (Figure 1B). Aluminium cathode used was $10 \mathrm{~cm}$ long, $8 \mathrm{~cm}$ width and $0.2 \mathrm{~cm}$ thick. Surface area for charcoal anode and aluminium cathode was $90.71 \mathrm{~cm}^{2}$ and $167.2 \mathrm{~cm}^{2}$, respectively.

\section{Preparations of anolyte and catholyte solutions}

Anolyte solution or substrate used was wastewater collected as fresh incoming sewage from University of Dar es Salaam wastewater stabilization ponds. Nzabuheraheza et al. (2012), reported that inflow sewage to University of Dar es Salaam constructed wetland has total dissolved solids (TDS) of $790.0 \pm 160.9$ $\mathrm{mg} / \mathrm{l}$ and total suspended solids (TSS) of about $416.2 \pm 61.1 \mathrm{mg} / \mathrm{l}$ while chemical oxygen demand (COD) is $450.6 \pm 73.9$ $\mathrm{mg} / \mathrm{l}$. Biological oxygen demand (BOD) is $347.2 \pm 23.5 \mathrm{mg} / \mathrm{l}$

Methylene blue $\left(\mathrm{C}_{37} \mathrm{H}_{27} \mathrm{~N}_{3} \mathrm{Na}_{2} \mathrm{O}_{9} \mathrm{~S}_{3}\right)$ was selected for use as a mediator (Taskan et al., 2015). The two catholytes used are phosphate buffer solution and ash water solution. Phosphate buffer solution of 10 $\mathrm{pH}$ and $1 \mathrm{M}$ was prepared by adding $0.7 \mathrm{~L}$ of potassium dihydrogen phosphate $\left(\mathrm{KH}_{2} \mathrm{PO}_{4}\right)$ solution to $1.3 \mathrm{~L}$ of $1 \mathrm{M}$ sodium hydroxide $(\mathrm{NaOH})$. Ash-water solution of $\mathrm{pH} 10$ and concentration of $15 \mathrm{~g} / \mathrm{L}$ was prepared by dissolving $30 \mathrm{~g}$ of ashes in $2 \mathrm{~L}$ of distilled water. Then, two polyethylene containers connected by the salt bridge, were filled with $2 \mathrm{~L}$ each of anolyte and catholyte solutions, respectively. Anode charcoal and cathode aluminium were totally immersed and hence connected by using $0.15 \mathrm{~cm}$ copper cables (Figure 1A).

\section{Equipment used}

The following equipment were used;

a) Fluke 289/FVF multi-meter with data logging capacity for voltage and current measurements, with IEC/EN 61010-1 complience.

b) Electrical heater for $\mathrm{NaCl}$ solution and agar heating.

c) Digital $\mathrm{pH}$ meter. 


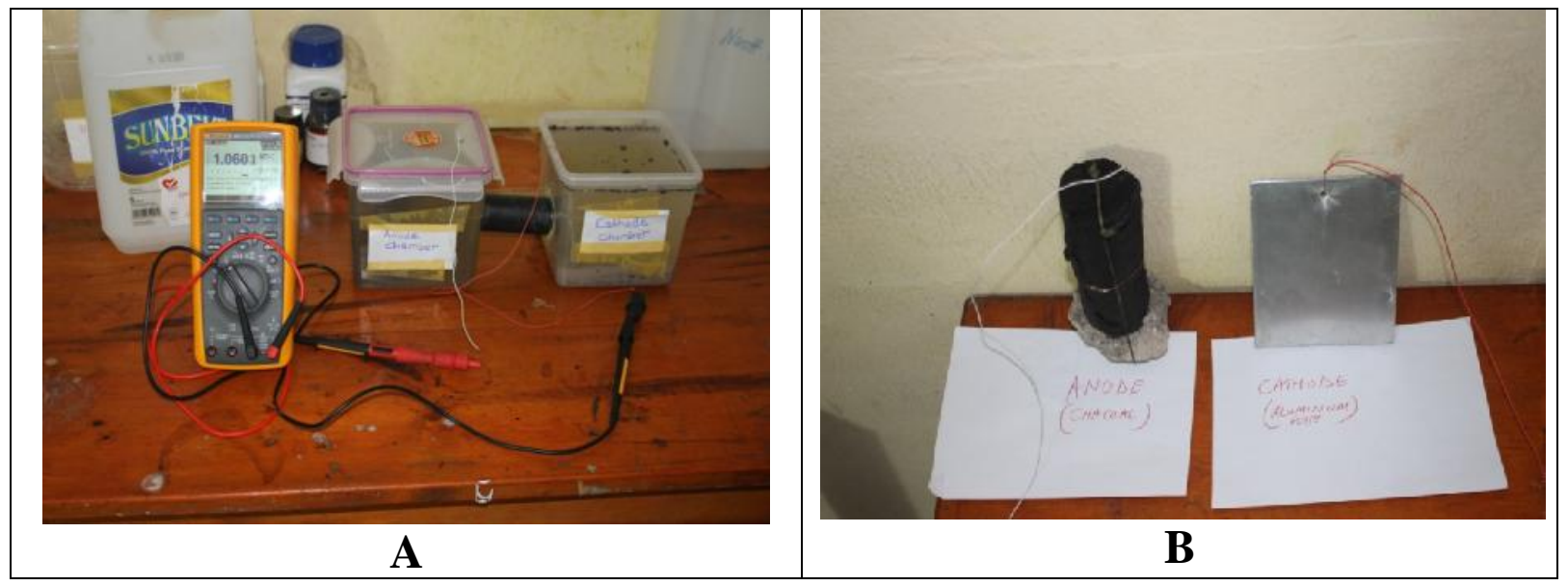

Figure 1: Experimental set-up (A) and charcoal anode and Al-cathode (B)

\section{Experimental methods}

Six sets of anolyte with methyl blue concentration of $0,100,200,300,400$ and $500 \mu \mathrm{M}$ were used. Experiments were conducted for both catholyte solutions, phosphate buffer solution and ash-water solution. Results for six levels of methylene blue concentration were compared on basis of the two catholyte solutions. Optimum concentration of methylene blue in anolyte used as anolyte solution was determined with respect to resulting voltage, current and anodic power density, after three hours of operation of the MFC. Hence, methyl blue concentration that yielded highest voltage, current and anodic power density was selected was selected as optimum and considered for further performance tests.

Determination of performance of methylene blue in MFC was carried out for anolyte solution with methyl blue addition.
Duration for this set of experiments was 24 hours and covered both catholytes, phosphate buffer solution and ash water solution. Variation of voltage and current with methyl blue addition in anolyte solution were compared with results obtained from mediatorless set-up for both catholyte solutions, phosphate buffer solution and ash-water solution. Lohar et al. (2014) also investigated performance of MFC on 24 hours basis, but Permana et al. (2015) opted for 36 hours period.

Each set of experiment was conducted three times, among these some were affected by noises caused by unintended interference such as physical interference of measurement cables, loss of data owing to low voltage battery cut-off points during 24 hours period of experiments. Therefore, data presented in this paper represent single valued data selected from three sets of replicates.

$$
\mathrm{C}_{12} \mathrm{H}_{22} \mathrm{O}_{11}+13 \mathrm{H}_{2} \mathrm{O} \rightarrow 12 \mathrm{H}_{2} \mathrm{O}+48 \mathrm{H}^{+}+48 e^{-}
$$

\section{Cell reactions and anodic power density}

Cathodic reaction for MFC using sewage as substrate, can be represented as sugar consumed by the microorganisms under anaerobic condition leading to production of carbon dioxide, protons and electrons
(Chonde, 2014). Anodic reaction involves oxygen reduction to form hydroxide ions with protons available from water.

$$
\mathrm{O}_{2}+4 e^{-}+4 \mathrm{H}^{+} \rightarrow 2 \mathrm{H}_{2} \mathrm{O}
$$


Cation transfer from the anolyte to the catholyte ensures electro-neutrality. It can be noted that, as for the case of equation (1), similar reactions can be deduced from reaction of sucrose, glucose and acetate (Ghangrekar and Shinde, 2006).

Power was calculated from equation (3) in which voltage and current represent measured values.

Power $=$ Voltage $\times$ Current........

Anodic power density, $\mathrm{P}_{\mathrm{d}}$ was determined by using equation (4) as suggested by Permana et al. (2015). The power was derived from measured values of voltage and current.

$$
P_{d}=\frac{P}{A}
$$

Where $\mathrm{P}$ is power and $\mathrm{A}$ is the surface area of the anode.

\section{RESULTS AND DISCUSSION}

\section{Optimum concentration of Methyl blue}

Figure 2 shows voltage variation with methyl blue concentration for phosphate buffer and ash-water catholytes. For the case of phosphate buffer catholyte, it was observed that voltage output increased from $1.265 \mathrm{~V}$ to $1.349 \mathrm{~V}$ with increase in methyl blue concentration in anolyte solution from $0 \mu \mathrm{M}$ to $300 \mu \mathrm{M}$. However, further increase in methyl blue concentration to $400 \mu \mathrm{M}$ and $500 \mu \mathrm{M}$ resulted to slight decrease in voltage output to $1.347 \mathrm{~V}$ and 1.343, respectively. For ash-water catholyte, voltage output increased from $1.221 \mathrm{~V}$ to $1.331 \mathrm{~V}$ before decreasing to $1.317 \mathrm{~V}$ when methyl blue concentration was increased from $0 \mu \mathrm{M}$, to $300 \mu \mathrm{M}$ and $500 \mu \mathrm{M}$, respectively.

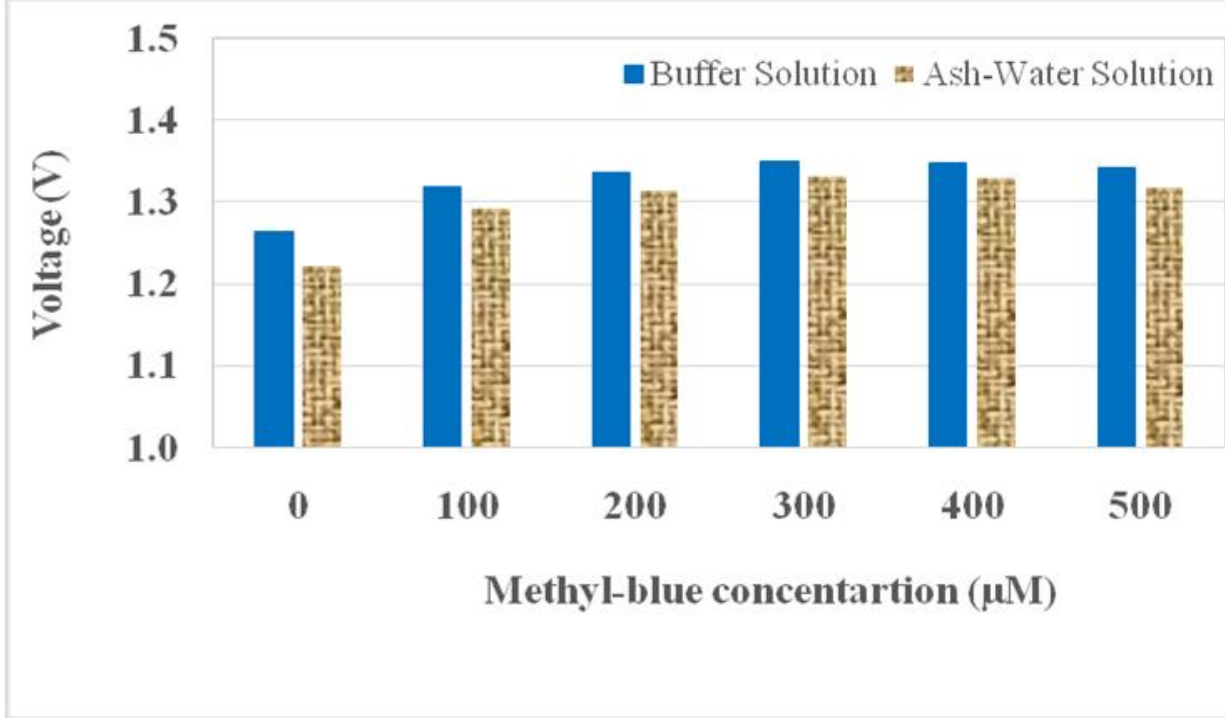

Figure 2: Voltage variation with methyl-blue concentration for phosphate buffer and ash-water catholytes

Figure 3 shows current variation with methyl blue concentration for phosphate buffer and ash-water catholytes. It was observed that for phosphate buffer catholyte current output increased from $0.403 \mathrm{~mA}$ to $0.485 \mathrm{~mA}$ with increase in methyl blue concentration in anolyte solution up to $300 \mu \mathrm{M}$. Nevertheless, current reading decreased to $0.477 \mathrm{~mA}$ and to $0.468 \mathrm{~mA}$ with increase in methyl blue concentration from $400 \mu \mathrm{M}$ to $500 \mu \mathrm{M}$, respectively. For ash-water catholyte, current output increased from $0.275 \mathrm{~mA}$ to $0.381 \mathrm{~mA}$ and then decreased $0.354 \mathrm{~mA}$ when methyl blue concentration was increased from $0 \mu \mathrm{M}$ to $300 \mu \mathrm{M}$ and hence to $500 \mu \mathrm{M}$, correspondingly. 


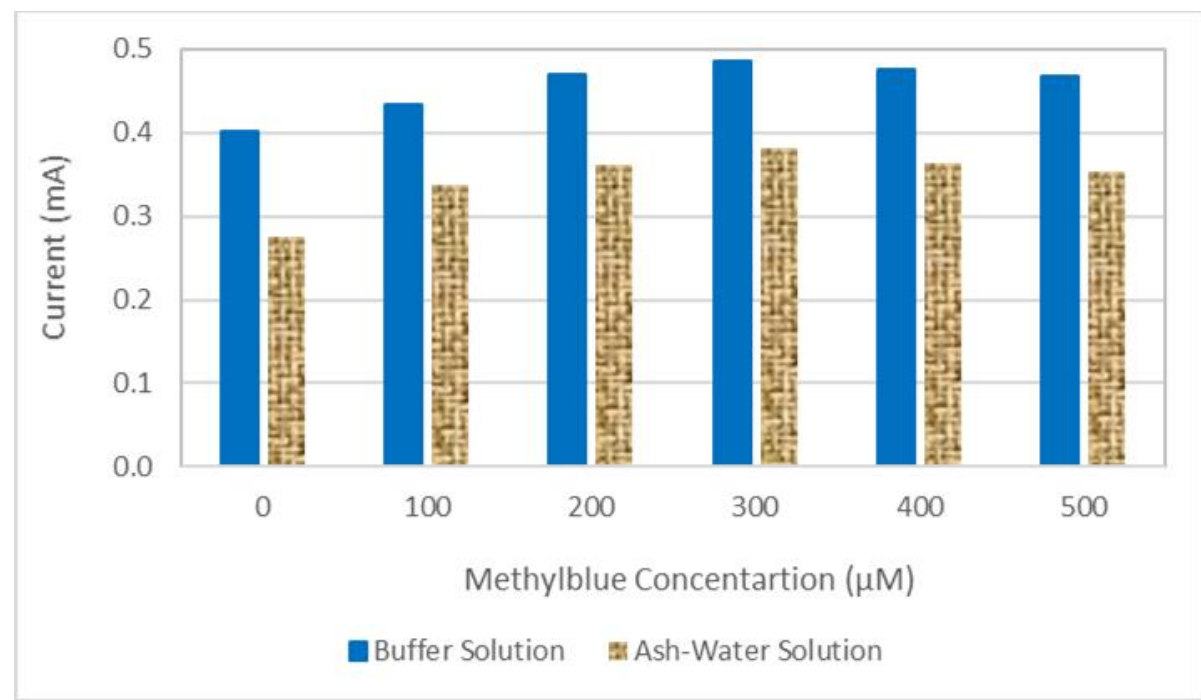

\section{Figure 3: Current variation with methyl blue concentration for phosphate buffer and ash water catholytes}

Figure 4 shows anodic power density variation with methyl blue concentration for phosphate buffer and ash-water catholytes. For phosphate buffer catholyte, anodic power density increased from 56.12 $\mathrm{mW} / \mathrm{m}^{2}$ to $72.15 \mathrm{~mW} / \mathrm{m}^{2}$ with increase in methyl blue concentration in anolyte solution up to $300 \mu \mathrm{M}$. Nevertheless, power density decreased to $69.31 \mathrm{~mW} / \mathrm{m}^{2}$ with increase in methyl blue concentration to $500 \mu \mathrm{M}$, correspondingly. For ash-water catholyte, power density increased from $37.07 \mathrm{~mW} / \mathrm{m}^{2}$ to $55.95 \mathrm{~mW} / \mathrm{m}^{2}$ and then decreased $51.43 \mathrm{~mW} / \mathrm{m}^{2}$ when methyl blue concentration was increased from $0 \mu \mathrm{M}$ to $300 \mu \mathrm{M}$ and hence to $500 \mu \mathrm{M}$, correspondingly.

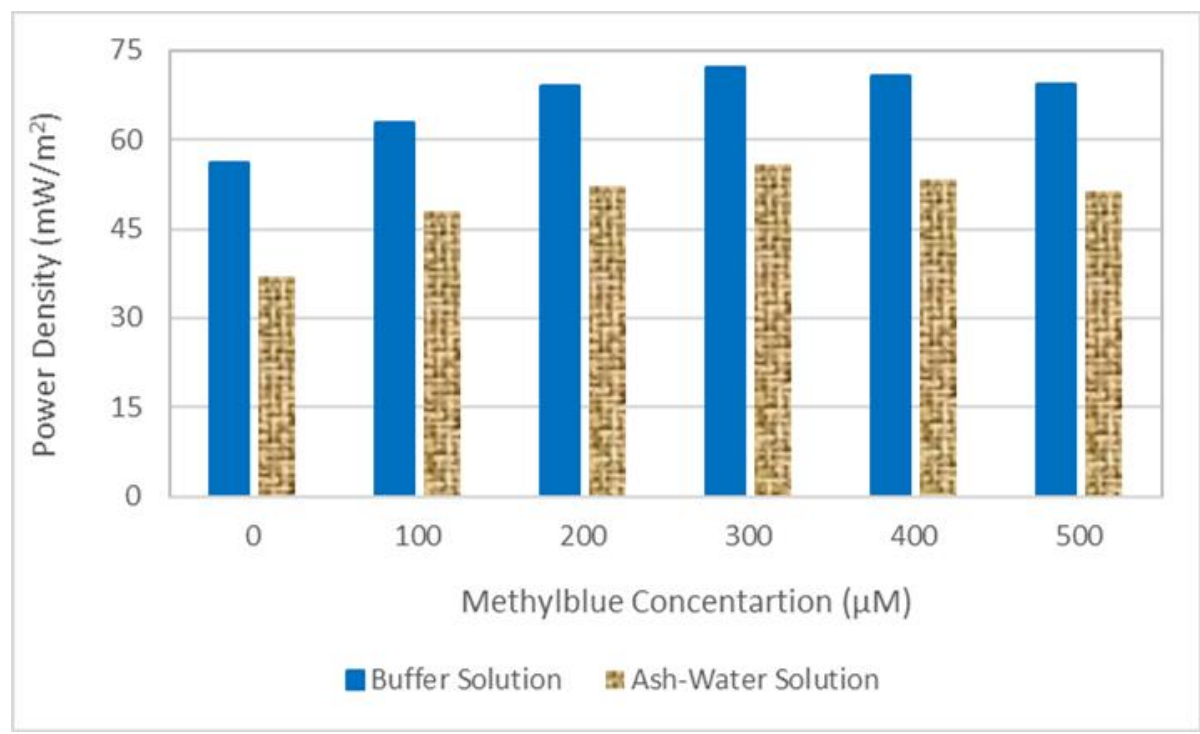

Figure 4: Power density variation with methyl-blue concentration for phosphate buffer and ash-water catholytes

Figures 2 to 4 , shows that microbial fuel cell generated $1.265 \mathrm{~V}, 0.403 \mathrm{~mA}$ and
$56.12 \mathrm{~mW} / \mathrm{m}^{2}$ after three hours of operation without addition of methyl blue 
into sewage anolyte. Correspondingly, with $300 \mu \mathrm{M}$ methyl blue in sewage anolyte, fuel cell produced $1.349 \mathrm{~V}, 0.485$ $\mathrm{mA}$ and $72.15 \mathrm{~mW} / \mathrm{m}^{2}$ after three hours. This is equivalent to $6.7 \%$ increase in voltage, $20.5 \%$ increase in current and $28.6 \%$ increase in power density. However, $500 \mu \mathrm{M}$ methyl blue in anolyte resulted in slight decrease in cell output to $1.343 \mathrm{~V}, 0.468 \mathrm{~mA}$ and $69.31 \mathrm{~mW} / \mathrm{m}^{2}$. Similarly, microbial fuel cell with ashwater anolyte generated $1.221 \mathrm{~V}, 0.275$ $\mathrm{mA}$ and $37.07 \mathrm{~mW} / \mathrm{m}^{2}$ after three hours of operation (Figures 2 to 4). However, with $300 \mu \mathrm{M}$ methyl blue in sewage anolyte, the cell produced $1.331 \mathrm{~V}, 0.381 \mathrm{~mA}$ and $55.95 \mathrm{~mW} / \mathrm{m}^{2}$ after three hours. This increase is equivalent $9.0 \%$ for voltage, $38.5 \%$ for current and $50.9 \%$ for power density. In addition, slight decrease in cell output to $1.317 \mathrm{~V}, 0.354 \mathrm{~mA}$ and 51.43 $\mathrm{mW} / \mathrm{m}^{2}$ was observed with $500 \mu \mathrm{M}$ methyl blue in anolyte. It can be noted that with reference to any specific methyl blue concentration in anolyte, the difference in current is larger than the difference in voltage. This phenomena indicates that methyl blue acts as electron mediator that accelerate electron transfer leading to improved current flow (Davis and Higson, 2007; Permana et al., 2015).

Compared to $100 \mu \mathrm{M}, 200 \mu \mathrm{M}, 400 \mu \mathrm{M}$ and $500 \mu \mathrm{M}$ concentration of methyl blue in anolyte solution, $300 \mu \mathrm{M}$ yielded highest voltage, current and anodic power density for both phosphate buffer and ashwater catholytes. Hence, $300 \mu \mathrm{M}$ methyl blue in anolyte was selected as optimum concentration. Similarly, Taskan et al. (2014) investigated the effect of $0 \mu \mathrm{M} 50$, $50 \mu \mathrm{M}, 100 \mu \mathrm{M}, 200 \mu \mathrm{M}, 300 \mu \mathrm{M}, 400$ $\mu \mathrm{M}$ and $500 \mu \mathrm{M}$ concentration of methyl blue in anolyte. As a result, $300 \mu \mathrm{M}$ concentration of methyl blue was selected as optimum concentration after observation of $101 \%$ increase in average power density from $17.9 \mathrm{~mW} / \mathrm{m}^{2}$ without methyl blue to $36 \mathrm{~mW} / \mathrm{m}^{2}$.

\section{Performance under phosphate buffer catholyte}

Figure 5A shows voltage variation in 24 hours of operation of MFC with phosphate buffer catholyte. Without methyl blue addition, the voltage was recorded at 0.829 $\mathrm{V}$ at commencement of the experiment when electrodes were dipped into anolyte and catholyte. Then, the voltage increased to $1.167 \mathrm{~V}$ and $1.260 \mathrm{~V}$ corresponding to one and two hours of continuous operation. Thereafter, the voltage increased gradually to $1.327 \mathrm{~V}$ after 24 hours of operation. With $300 \mu \mathrm{M}$ concentration of methyl blue in anolyte solution, the voltage was $1.094 \mathrm{~V}$ at the beginning of the experiment and increased to $1.346 \mathrm{~V}$ after two hours of operation. Even after 24 hours of operation, the voltage remained almost stable with slight increased to $1.381 \mathrm{~V}$.

Figure 5B shows current variation in 24 hours of operation of MFC with phosphate buffer catholyte. Without methyl blue addition, current was recorded at 0.796 $\mathrm{mA}$ during the initiation of the experiment, and then dropped abruptly to $0.456 \mathrm{~mA}$ in two hours of operation. Afterwards, the current decreased steadily to $0.261 \mathrm{~mA}$ after 24 hours. With $300 \mu \mathrm{M}$ concentration of methyl blue in anolyte solution, the current was $1.152 \mathrm{~mA}$ at the start of the experiment and decreased to $538 \mathrm{~mA}$ in two hours. However, it was observed that current slightly increased $0.521 \mathrm{~mA}$ five hours later. Subsequently, the current remained almost stable for other eight hours before decreasing back to $0.453 \mathrm{~mA}$ after 24 hours of operation. 


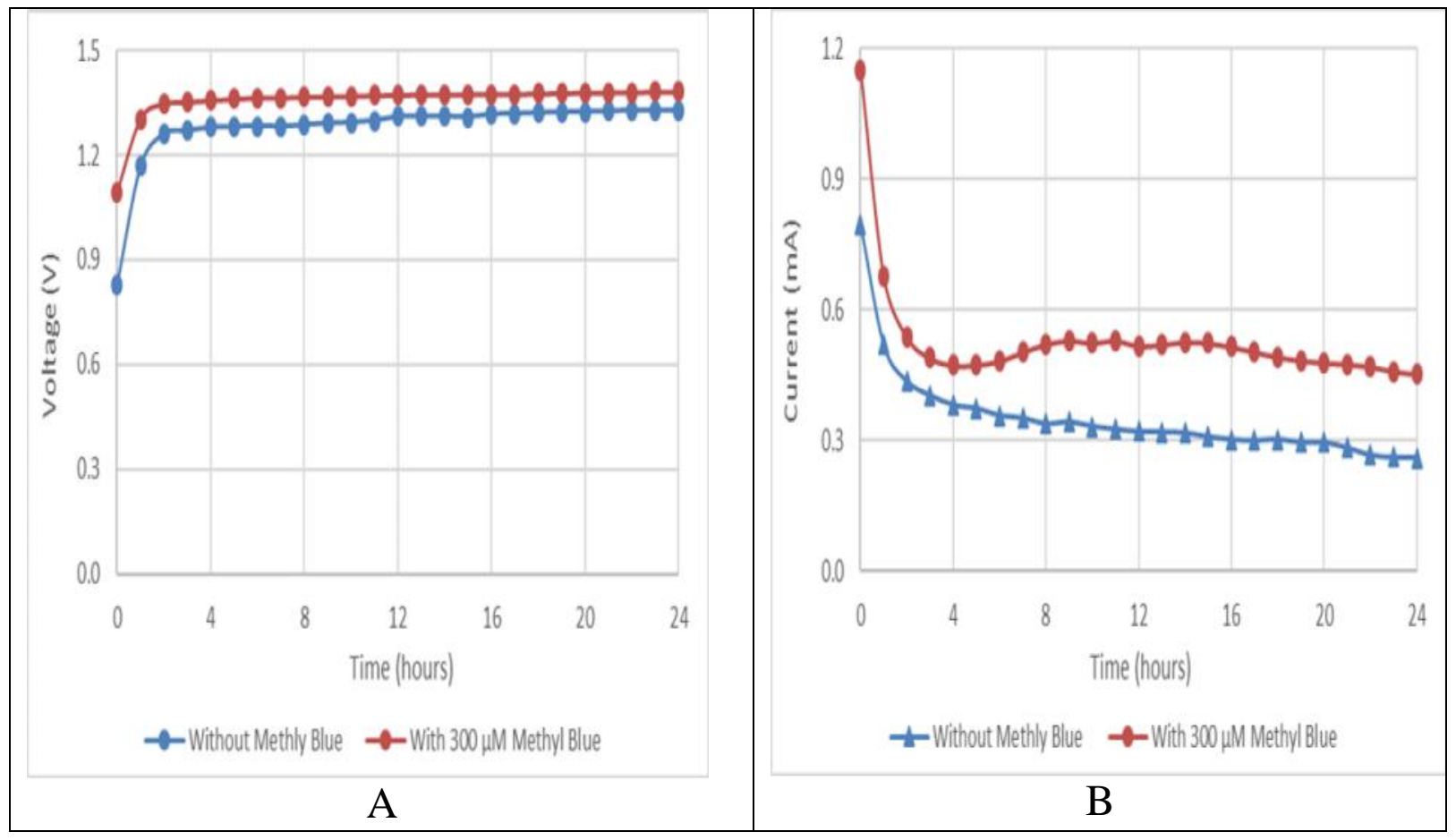

Figure 5: Variation of voltage (A) and current (B) in 24 hours of operation of MFC with phosphate buffer catholyte

Between three and twenty four hours of continuous operation of the microbial fuel cell, the average voltage was $1.305 \mathrm{~V}$ with phosphate buffer catholyte and without addition of methyl blue in anolyte (Figure 5A). With $300 \mu \mathrm{M}$ concentration of methyl blue in anolyte, the voltage remained almost stable at average of $1.371 \mathrm{~V}$ during the similar span of period. With phosphate buffer catholyte, the average current was $0.321 \mathrm{~mA}$ without addition of methyl blue in anolyte (Figure 5B). With $300 \mu \mathrm{M}$ concentration of methyl blue, the average current increased to $0.498 \mathrm{~mA}$. In comparison to fuel cell operation without methyl blue addition in anolyte, $300 \mu \mathrm{M}$ concentration of methyl blue lead to $5.1 \%$ increase in voltage, $55.2 \%$ increase in current and consequently $63.3 \%$ increase in power density. Permana et al. (2015) referring to 36 hours of MFC operation, observed $28.7 \%$ increase in average voltage from $0.689 \mathrm{~V}$ without methyl blue to $0.887 \mathrm{~V}$ with methyl blue in anolyte. Similarly, Lohar et al. (2014) reported $11.8 \%$ increase in average voltage from
$0.68 \mathrm{~V}$ without methyl blue and $0.76 \mathrm{~V}$ with methyl blue equivalent.

\section{Performance under ash-water catholyte}

Figure 6A shows voltage variation in 24 hours of operation of MFC with ash-water catholyte. Without methyl blue addition, the voltage was recorded at $1.013 \mathrm{~V}$ at start of the experiment. The voltage increased to $1.197 \mathrm{~V}$ and $1.222 \mathrm{~V}$ after one and two hours of operation, respectively. Subsequently, the voltage decreased to $1.209 \mathrm{~V}$ after 24 hours of operation. With $300 \mu \mathrm{M}$ concentration of methyl blue in anolyte solution, the voltage was $1.231 \mathrm{~V}$ at the beginning of the experiment before increasing to $1.331 \mathrm{~V}$ after two hours of operation. The voltage dropped to $1.272 \mathrm{~V}$ after 24 hours of operation.

Figure 6B shows current variation in 24 hours of operation of MFC with ash-water catholyte. Without methyl blue addition, current was recorded at $0.541 \mathrm{~mA}$ during the beginning of the experiment, and then 
dropped to $0.275 \mathrm{~mA}$ in two hours of operation. Thereafter, the current decreased steadily to $0.219 \mathrm{~mA}$ after 24 hours. With $300 \mu \mathrm{M}$ concentration of methyl blue in anolyte solution, current was $0.845 \mathrm{~mA}$ at the start of the experiment and decreased sharply to 0.370 $\mathrm{mA}$ in two hours. However, it was observed that current slightly increased to $0.430 \mathrm{~mA}$ after three hours later. Subsequently, the current remained almost stable for other six hours before decreasing further to $0.310 \mathrm{~mA}$ after 24 hours of operation.

By using ash-water as catholyte, microbial fuel cell provided the average voltage of $1.222 \mathrm{~V}$ between three and twenty four hours of operation with phosphate buffer catholyte and without addition of methyl blue in anolyte (Figure 6A). With $300 \mu \mathrm{M}$ concentration of methyl blue in anolyte, the average voltage was $1.298 \mathrm{~V}$ during the similar period of operation. With phosphate buffer catholyte, the average current was $0.244 \mathrm{~mA}$ without addition of methyl blue in anolyte (Figure 6B). With $300 \mu \mathrm{M}$ concentration of methyl blue, the average current $0.388 \mathrm{~mA}$. In comparison to fuel cell operation without methyl blue addition in anolyte, $300 \mu \mathrm{M}$ concentration of methyl blue lead to $6.2 \%$ increase in voltage, $59.1 \%$ increase in current and hence $69.1 \%$ increase in power density. Similarly, Permana et al. (2015) observed over $111 \%$ increase in average power density from $2.12 \mathrm{~mW} / \mathrm{m}^{2}$ without methyl blue to $4.48 \mathrm{~mW} / \mathrm{m}^{2}$ with methyl blue. Correspondingly, Lohar et al. (2014) observed $25.0 \%$ increase in average power density from $8.99 \mathrm{~mW} / \mathrm{m}^{2}$ without methyl blue to $11.24 \mathrm{~mW} / \mathrm{m}^{2}$ with methyl blue.

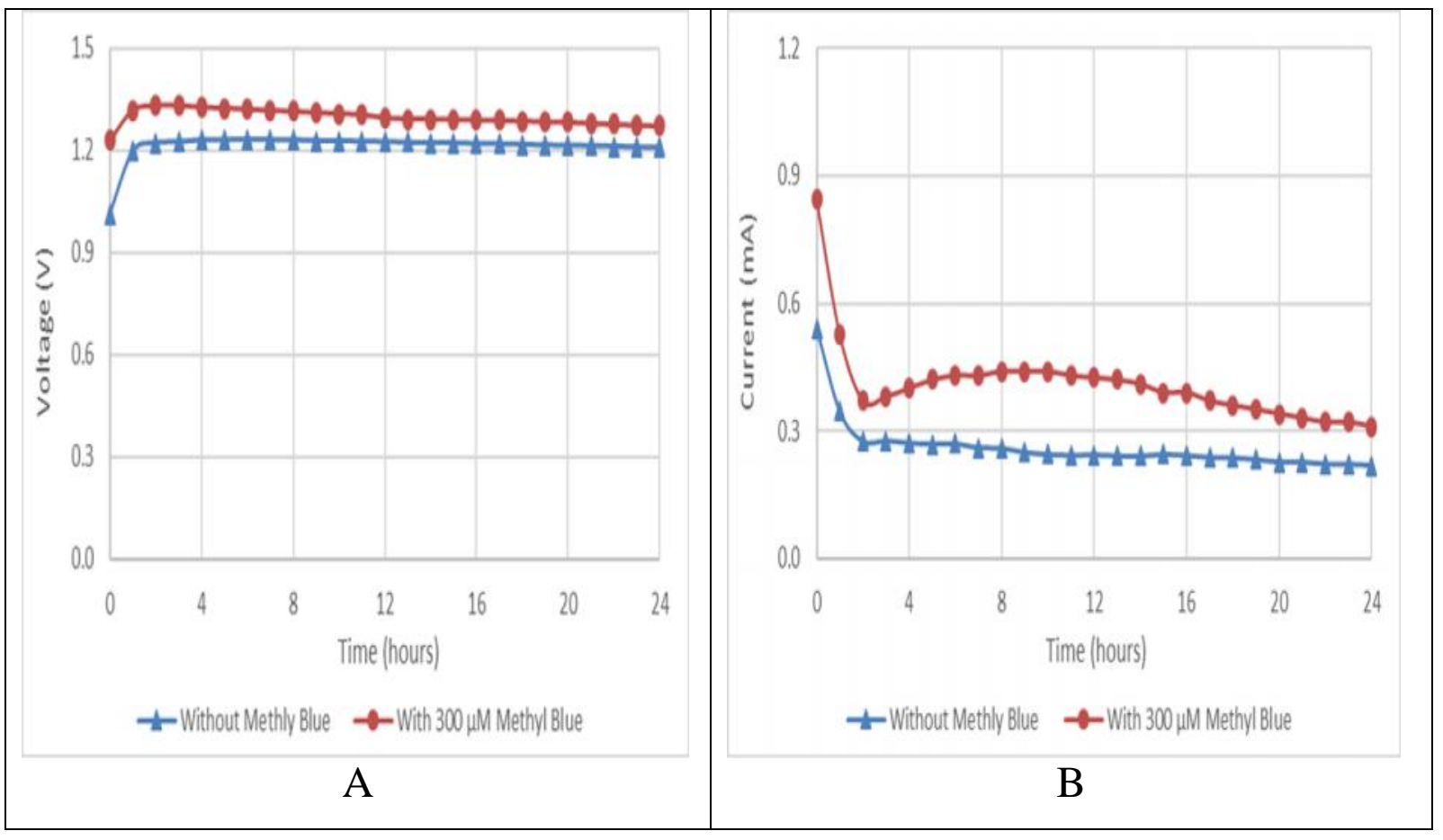

Figure 6: Variation of voltage (A) and current (B) in 24 hours of operation of MFC with ash-water catholyte 
Without addition of methyl blue to anolyte, between three and twenty four hours of operation of the microbial fuel cell using phosphate buffer catholyte produced higher average voltage and current of about $1.305 \mathrm{~V}$ and $0.321 \mathrm{~mA}$ (Figure 5) as compared to ash-water catholyte which attained $1.222 \mathrm{~V}$ and $0.244 \mathrm{~mA}$ (Figure 6). Therefore, without addition of methyl blue to anolyte, use of ash-water catholyte reduced voltage, current and subsequently power density to by $6.4 \%, 23.8 \%$ and $28.5 \%$ as compared to when phosphate buffer catholyte was used. With $300 \mu \mathrm{M}$ concentration methyl blue in anolyte, higher average voltage and current of about $1.371 \mathrm{~V}$ and $0.498 \mathrm{~mA}$ was also produced by using phosphate buffer catholyte (Figure 5) as compared to ashwater catholyte which attained $1.298 \mathrm{~V}$ and $0.388 \mathrm{~mA}$ (Figure 6). Therefore, with $300 \mu \mathrm{M}$ concentration methyl blue of methyl blue in anolyte, use of ash-water catholyte reduced voltage, current and subsequently power density to by $5.3 \%$, $21.9 \%$ and $26.0 \%$ as compared to when phosphate buffer catholyte was used.

\section{CONCLUSIONS}

After three hours of operation microbial fuel cell without addition of methyl blue into sewage anolyte, its output was 1.265 $\mathrm{V}, 0.403 \mathrm{~mA}$ and $56.12 \mathrm{~mW} / \mathrm{m}^{2}$. With 300 $\mu \mathrm{M}$ methyl blue in sewage anolyte, $6.7 \%$ increase in voltage, $20.5 \%$ increase in current and $28.6 \%$ increase in power density equivalent to $1.349 \mathrm{~V}, 0.485 \mathrm{~mA}$ and $72.15 \mathrm{~mW} / \mathrm{m}^{2}$, respectively. By using ash-water anolyte, the cell generated 1.221 $\mathrm{V}, 0.275 \mathrm{~mA}$ and $37.07 \mathrm{~mW} / \mathrm{m}^{2}$ after three hours of operation. With $300 \mu \mathrm{M}$ methyl blue in sewage anolyte, the cell generated $1.331 \mathrm{~V}, 0.381 \mathrm{~mA}$ and $55.95 \mathrm{~mW} / \mathrm{m}^{2}$, which is equivalent to increase of $9.0 \%$ in voltage, $38.5 \%$ in current and $50.9 \%$ for power density. With reference to specific methyl blue concentration in anolyte, the difference in current is larger than the difference in voltage. Compared to 100 $\mu \mathrm{M}, 200 \mu \mathrm{M}, 400 \mu \mathrm{M}$ and $500 \mu \mathrm{M}$ concentration of methyl blue in anolyte solution, $300 \mu \mathrm{M}$ yielded the highest voltage, current and anodic power density for both phosphate buffer and ash-water catholytes. Hence, $300 \mu \mathrm{M}$ methyl blue in anolyte was selected as optimum concentration.

Between three and twenty four hours of continuous operation of the microbial fuel cell with phosphate buffer catholyte, the average voltage was $1.305 \mathrm{~V}$ without addition of methyl blue in anolyte and $1.371 \mathrm{~V}$ when $300 \mu \mathrm{M}$ concentration of methyl blue was used in anolyte. Similarly, the average current was 0.321 $\mathrm{mA}$ before addition of methyl blue and increased to $0.498 \mathrm{~mA}$ when anolyte had $300 \mu \mathrm{M}$ concentration of methyl blue. Therefore methyl blue addition with phosphate buffer catholyte, led to $5.1 \%$ increase in voltage, $55.2 \%$ increase in current and consequently $63.3 \%$ increase in power density. By using ash-water as catholyte, average voltage of $1.222 \mathrm{~V}$ while average current was $0.244 \mathrm{~mA}$ without addition of methyl blue in anolyte. With $300 \mu \mathrm{M}$ concentration of methyl blue in anolyte, the average voltage and average current increased to $1.298 \mathrm{~V}$ and 0.388 $\mathrm{mA}$, respectively. This is equivalent to $6.2 \%$ increase in voltage, $59.1 \%$ increase in current and hence $69.1 \%$ increase in power density for ash-water as catholyte.

\section{ACKNOWLEDGEMENT}

This work was supported by the NORAD under the Energy and Petroleum (EnPe) Program at the University of Dar es Salaam, Tanzania and Norwegian University of Science and Technology, Trondheim, Norway.

\section{REFERENCES}

Cheng X., Shi Z., Glass N., Zhang L. and Zhang J. (2004). A review of PEM hydrogen fuel cell contamination: 
Impacts, mechanisms, and mitigation. Journal of Power Sources, 305: 12801283.

Chonde A.G. (2014). Microbial Fuel cell: A New Approach of Wastewater Treatment with Power Generation. International Journal of Chemical, Environmental and Pharmaceutical Research, 5(1): 8-12.

Davis F. and Higson S.P.J. (2007). Biofuel cells - Recent advances and applications. Biosensors and Bioelectronics, 22(7): 1224-1235.

Ghangrekar M.M. and Shinde V.B. (2006). Microbial Fuel Cell: A New Approach of Wastewater Treatment with Power Generation. Proceeding of International Workshop on R\&D Frontiers in Water and Wastewater Management, 686-697.

Ieropoulos I.A., Greenman J., Melhuish C. and Hart J. (2005). Energy accumulation and improved performance in microbial fuel cells. Journal of Power Sources, 145(2): 253-256.

Katz E., Shipway A. and Willner I. (2003). Handbook of fuel cells Fundamentals, technology and applications. $1^{\text {st }}$ Edition, John Wiley \& Sons.

Kihedu J. and Mhilu C.F. (2012). Wind Resource Assessment in Tanzania; Power Generation Potential in Tanzania. The Tanzania Engineer, 12(1): 56-62.

Kimambo C.Z.M. and Kihedu J. (2008). A Cost Effective Model for Solar Powered Rural Electrification. The Tanzania Engineer, 8(4): 19 - 30.

Li W., Yu H. and He Z. (2014). Towards sustainable wastewater treatment by using microbial fuel cells-centered technologies. Energy and Environmental Science, 7(3): 911924.

Logan B.E., Hamelers B., Rozendal R.A., Schrorder U., Keller J. and Freguia S. (2006). Microbial fuel cells: Methodology and technology,
Environmental Science and Technology, 40: 5181-5192.

Logan B.E. and Regan J.M. (2006). Microbial fuel cells-challenges and applications. Environmental Science and Technology, 40(17): 5172-5180.

Lohar S.A., Patil V.D. and Patil D.B. (2014). Role of Mediators in Microbial Fuel Cell for Generation of Electricity and Waste Water Treatment. International Journal of Chemical Sciences and Applications, 6(1): 6-11.

Nzabuheraheza F.D., Katima J.H.Y., Njau K.N., Kayombo S. and Niyigena N.A. (2012). Wastewater Treatment for Pollution Control. Rwanda Journal of Health Sciences, 1(1): 1-7.

Park D. and Zeikus J. (2000). Electricity generation in microbial fuel cells using neutral red as an electronophore, Applied and Environmental Microbiology, 66: 1292-1299.

Parkash A., Aziz S. and Soomro S.A. (2015). Utilization of Sewage Sludge for Production of Electricity using Mediated Salt Bridge Based Dual Chamber Microbial Fuel Cell. Bioprocessing and Biotechniques, 5(8): 251-255.

Permana D., Rosdianti D., Ishmayana S., Rachman S.D., Putra H.E., Rahayuningwulan D. and Hariyadi H.R. (2015). Preliminary Investigation of Electricity Production Using Dual Chamber Microbial Fuel Cell (DCMFC) with Saccharomyces cerevisiae as Biocatalyst and Methylene Blue as an Electron Mediator. Procedia Chemistry, 17: 36-43.

Rabaey K., Ossieur W., Verhaege M., and Verstraete W. (2005). Continuous microbial fuel cells convert carbohydrates to electricity. Water Science and Technology, 52(2): 515523.

Taskan E., Ozkaya B. and Hasar H. (2015). Combination of a novel 
electrode material and artificial mediators to enhance power generation in an MFC. Water Science and Technology, 71(3): 320-328.

Taskan E., Özkaya B. and Hasar H. (2014). Effect of different mediator concentrations on power generation in MFC using $\mathrm{Ti}^{-} \mathrm{TiO}_{2}$ electrode. International Journal of Energy Science, 4(1): 9-11.

You S., Zhao Q., Zhang J., Jiang J. and Zhao S. (2006). A microbial fuel cell using permanganate as the cathodic electron acceptor. Journal of Power Sources, 162: 1409-1415.

Zhao F., Harnisch F., Schroder U., Scholz, F. and Bogdanoff P. (2006). Application of pyrolyzed iron (II) phthalocyanine and CoTMPP based oxygen reduction catalysts as cathode materials in microbial fuel cells. Electrochemistry Communication, 7: 1405-1410. 